\title{
Antihyperglycemic and Antihyperlipidaemic effect of Polygala rosmarinifolia Wright $\&$ Arn on alloxan induced diabetic rats
}

\author{
M. Alagammal ${ }^{1}$, A. Nishanthini ${ }^{2}$, V.R. Mohan $^{2} *$ \\ ${ }^{1}$ Department of Botany, Government Siddha Medical College, Palayamkottai, Tamil Nadu. \\ ${ }^{2}$ Ethnopharmacology Unit, Research Department of Botany, V. O. Chidambaram College, Tuticorin, Tamil Nadu.
}

\section{ARTICLE INFO}

Article history:

Received on: 08/09/2012

Revised on: 19/09/2012

Accepted on: 24/09/2012

Available online:

Key words:

Antihyperlipidaemic,

Antihyperglycemic,

P. rosmarinifolia,

Alloxan and Glibenclamide.

\begin{abstract}
The ethanol extract of Polygala rosmarinifolia whole plant (Family: Polygalaceae) was investigated for its antihyperglycemic and antihyperlipidaemic effect in Wistar Albino rats. Diabetes was induced in Albino rats by administration of alloxan monohydrate $(150 \mathrm{mg} / \mathrm{kg}$, i.p). The ethanol extracts of Polygala rosmarinifolia at a dose of 100 and $200 \mathrm{mg} / \mathrm{kg}$ of body weight were administered at single dose per day to diabetes induced rats for a period of 14 days. The effect of ethanol extract of Polygala rosmarinifolia whole plant extract on blood glucose, serum insulin, urea, creatinine, glycosylated haemoglobin, serum lipid profile [total cholesterol (TC), triglycerides (TG), low density lipoprotein - cholesterol (LDL-C), very low density lipoprotein-cholester (VLDL-C), high density lipoprotein - cholesterol (HDL-C) and phospholipid (PL)] serum protein, albumin, globulin, serum enzymes [serum glutamate pyruvate transaminases (SGPT), serum glutamate oxaloacetate transaminases (SGOT), and alkaline phosphatase (ALP)], were measured in the diabetic rats. The ethanol extract of Polygala rosmarinifolia whole plant elicited significant reductions of blood glucose $(P<0.05)$, lipid parameters except HDL-C, serum enzymes and significantly increased HDL-C. The extracts also caused significant increase in serum insulin $(P<0.05)$ in the diabetic rats. From the above results, it is concluded that ethanol extract of Polygala rosmarinifolia possesses significant antihyperglycemic and antihyperlipidaemic effects in alloxan induced diabetic rats.
\end{abstract}

\section{INTRODUCTION}

Diabetes mellitus (DM), a leading non communicable disease with multiple aetiologies, affects more than 100 million people Worldwide and is consider as one of the leading causes of death in the world (Zimmet, 1999). The World Health Organization (WHO) reported that 300 million peoples would suffer from diabetes mellitus by the year 2025 (Pradeepa and Mohan, 2002). Diabetes mellitus is characterized by an increased concentration of blood glucose due to derangement in carbohydrates metabolism and defective secretion of insulin. There metabolic disturbances result in acute and long term diabetic complications, which are responsible for premature death and disability (Aravind et al., 2002).

\footnotetext{
* Corresponding Author

Email:vrmohanvoc@gmail.com
}

Diabetes mellitus is a multifactorial disease which is characterized by hyperglycemia, lipoprotein abnormalities, raised basal metabolic rats, defects in reactive oxygen species scavenging enzymes and high oxidative stress induced damage to pancreatic beta cells (Ugochukwa and Babady, 2003; Scoppoia et al., 2001; Owu et al., 2006; Kesavalu et al., 2000). Diabetes mellitus is ranked seventh among the leading causes of death and is considered third when its fatal complications are taken into account (Trivedi $e t$ al., 2004; Sharma et al., 2010). In traditional practice, medicinal plants are used in many countries to control DM. The National Center for Complementary and Alternative Medicine, established in 1998 by the United States Government where development of herbal medicine is one of the important subjects of study (Yoon et al., 2004). WHO has recommended evaluation of plants effective in different diseases. Many Indian Medicinal plants have been found to be useful in successfully managing diabetes and from 
some of them active principles have been isolated (Shukla et al., 2000). Thus, it will be useful to look for new and if possible more efficacious drugs and the vast reserves of phytotherapy may be an ideal target. Polygala was traditionally used by Americans to treat snake bites and as an expectorant to treat cough and bronchitis Polygala is considered as a powerful tonic than can help to develop the mind and aid in creative thinking. To our knowledge no report on the effect of Polygala rosmarinifolia whole plant on experimental antidiabetic. This study was therefore undertaken to evaluate the effects an ethanol extract of whole plant of Polygala rosmarinifolia on antihyperglycemic and anti hyperlipidamic activity in alloxan induced diabetic rats.

\section{MATERIALS AND METHODS}

\section{Plant Material}

The whole plant of Polygala rosmarinifolia were freshly collected from the well grown healthy plants inhabiting the natural forests of Maruthamalai, Coimbatore, Tamil Nadu. The plant were identified and authenticated in Botanical Survey of India, Southern Circle, Coimbatore, Tamil Nadu, India. A voucher specimen was deposited in Ethnopharmacology Unit, Research Department of Botany, V.O.Chidambaram College, Tuticorin, Tamil Nadu.

\section{Preparation of plant extract for phytochemical screening and antidiabetic studies}

The Polygala rosmarinifolia whole plant were shade dried at room temperature and the dried whole plant were powdered in a Wiley mill. Hundred grams of powdered Polygala rosmarinifolia whole plant was packed in a Soxhlet apparatus and extracted with ethanol. The extract were subjected to qualitative test for the identification of various phytochemical constituents as per the standard procedures (Brinda et al., 1981; Lala, 1983). The ethanol extracts were concentrated in a rotary evaporator. The concentrated ethanol extract were used for antidiabetic studies.

\section{Animals}

Normal healthy male Wistar albino rats $(180-240 \mathrm{~g})$ were housed under standard environmental conditions at temperature $\left(25 \pm 2^{\circ} \mathrm{C}\right)$ and light and dark (12: $\left.12 \mathrm{~h}\right)$. Rats were fed with standard pellet diet (Goldmohur brand, MS Hindustan lever Ltd., Mumbai, India) and water ad libitum.

\section{Acute Toxicity Study}

Acute oral toxicity study was performed as per OECD 423 guidelines (acute toxic class method), albino rats $(n=6)$ of either sex selected by random sampling were used for acute toxicity study (OECD, 2002). The animals were kept fasting for overnight and provided only with water, after which the extracts were administered orally at $5 \mathrm{mg} / \mathrm{kg}$ body weight by gastric intubations and observed for 14 days. If mortality was observed in two out of three animals, then the dose administered was assigned as toxic dose. If mortality was observed in one animal, then the same dose was repeated again to confirm the toxic dose. If mortality was not observed, the procedure was repeated for higher doses such as 50,100, and $2000 \mathrm{mg} / \mathrm{kg}$ body weight.

\section{Induction of Diabetes in Experimental animal}

Rats were induced diabetes by the administration of simple intraperitoneal dose of alloxan monohydrate $(150 \mathrm{mg} / \mathrm{kg})$ (Nagappa et al., 2003). Two days after alloxan injection, rats screened for diabetes having glycosuria and hypoglycemia with blood glucose level of $200-260 \mathrm{mg} / 100 \mathrm{ml}$ were taken for the study. All animals were allowed free access to water and pellet diet and maintained at room temperature in plastic cages.

\section{Experimental Design}

In the present investigation, a total of 30 rats ( 24 diabetic surviving rats and 6 normal rats) were taken and divided into five groups of 6 rats each.

Group I: Normal untreated rats

Group II: Diabetic control rats

Group III: Diabetic rats given ethanol extract of Polygala rosmarinifolia whole plant $(100 \mathrm{mg} / \mathrm{kg}$ body weight)

Group IV: Diabetic rats given ethanol extract of Polygala rosmarinifolia whole plant $(200 \mathrm{mg} / \mathrm{kg}$ body weight)

Group V: Diabetic rats given standard drug glibenclamide (600 $\mu \mathrm{g} / \mathrm{kg}$ body weight).

The animals were sacrificed at the end of experimental period of 14 days by decapitation. Blood was collected, sera separated by centrifugation at $3000 \mathrm{~g}$ for 10 minutes.

Estimation of insulin, glucose, urea, creatinine and glycosylated haemoglobin

Serum glucose was measured by the O-toluidine method (Sasaki et al., 1972). Insulin level was assayed by Enzyme Linked Immunosorbant Assay (ELISA) kit (Anderson et al., 1993). Urea estimation was carried out by the method of Varley (Varley, 1976); serum creatinine was estimated by the method of (Owen $e t$ al., 1954 ). Glycosylated haemoglobin $\left(\mathrm{HBA}_{1} \mathrm{C}\right)$ estimation was carried out by a modified colorimetric method of Karunanayake and Chandrasekharan (1985).

\section{Estimation of protein, albumin, globulin, SGPT, SGOT, ALP}

Serum protein (Lowry et al., 1951) and serum albumins was determined by quantitative colorimetrically method by using bromocresol green. The total protein minus the albumin gives the globulin, serum glutamate pyruvate transaminase (SGPT) and serum glutamate oxaloacetate transaminase (SGOT) was measured spectrophotometrically by utilizing the method of Reitman and Frankel (1957). Serum alkaline phosphatase (ALP) was measured by the method of King and Armstrong (1934).

\section{Estimation of lipids and lipoprotein}

Serum total cholesterol (TC) (Parekh and Jung, 1970), total triglycerides (TG) (Rice, 1970), low density lipoprotein cholesterol (LDL-C), very low density lipoprotein cholesterol 
Table. 1: Effect of ethanol extract of Polygala rosmarinifolia whole plant on the serum insulin, glucose, urea, creatinine and $\mathrm{HBA}_{1} \mathrm{C}$ level of normal, diabetic induced and drug treated adult albino rats.

\begin{tabular}{llllll}
\hline Groups & $\begin{array}{l}\text { Glucose } \\
(\mathbf{m g} / \mathbf{d l})\end{array}$ & $\begin{array}{l}\text { Insulin } \\
(\mathbf{M I u} / \mathbf{m l})\end{array}$ & $\begin{array}{l}\text { Urea } \\
(\mathbf{m g} / \mathbf{d l})\end{array}$ & $\begin{array}{l}\text { Creatinine } \\
(\mathbf{m g} / \mathbf{d l})\end{array}$ & $\begin{array}{l}\text { HB } \mathbf{A}_{\mathbf{1}} \mathbf{C} \\
(\boldsymbol{\%})\end{array}$ \\
\hline I & $83.16 \pm 2.11$ & $14.27 \pm 0.74$ & $18.16 \pm 0.94$ & $0.69 \pm 0.03$ & $3.91 \pm 0.11$ \\
II & $231.84 \pm 18.43^{* *}$ & $5.21 \pm 0.24^{* *}$ & $36.69 \pm 1.14^{* *}$ & $0.93 \pm 0.04^{*}$ & $8.59 \pm 0.14^{* *}$ \\
III & $168.14 \pm 1.94^{\mathrm{a}}$ & $8.36 \pm 0.16^{\mathrm{a}}$ & $28.31 \pm 0.87^{\mathrm{a}}$ & $0.88 \pm 0.06$ & $6.39 \pm 0.13^{\mathrm{a}}$ \\
IV & $114.34 \pm 2.08^{* \mathrm{a}}$ & $11.96 \pm 0.26^{\mathrm{a}}$ & $14.54 \pm 0.26^{\mathrm{a}}$ & $0.73 \pm 0.08$ & $4.99 \pm 0.24^{\mathrm{a}}$ \\
V & $94.66 \pm 1.84^{\text {aa }}$ & $13.63 \pm 0.18^{\text {aa }}$ & $16.24 \pm 0.39^{\mathrm{a}}$ & $0.77 \pm 0.06$ & $4.07 \pm 0.14^{\mathrm{a}}$ \\
\hline
\end{tabular}

Each Value is $\mathrm{SEM} \pm 6$ individual observations $* P<0.05 ; * * P<0.01$ Compared normal control vs -Diabetic rats : a $-P<0.05 ;$ aa $-P<0.01$ Compared Diabetic rats vs drug treated.

Table. 2: Effect of ethanol extract of Polygala rosmarinifolia whole plant on the serum protein, albumin, globulin, SGOT, SGPT and ALP level of normal, diabetic induced and drug treated adult albino rats.

\begin{tabular}{lllllll}
\hline Parameter & Protein $(\mathbf{g} / \mathbf{d l})$ & Albumin $(\mathbf{g} / \mathbf{d l})$ & Globulin $(\mathbf{g} / \mathbf{d l})$ & SGPT $(\mathbf{u} / \mathbf{l})$ & SGOT $(\mathbf{u} / \mathbf{l})$ & ALP $(\mathbf{u} / \mathbf{l})$ \\
\hline Group I & $8.14 \pm 0.17$ & $4.50 \pm 0.18$ & $3.64 \pm 0.13$ & $18.31 \pm 0.61$ & $21.66 \pm 0.34$ & $120.16 \pm 4.11$ \\
Group II & $5.27 \pm 0.11^{*}$ & $2.32 \pm 0.13^{*}$ & $2.95 \pm 0.16^{*}$ & $29.11 \pm 0.36^{* *}$ & $34.16 \pm 0.71^{*}$ & $191.20 \pm 3.92^{* *}$ \\
Group III & $6.34 \pm 0.08$ & $3.48 \pm 0.06$ & $2.86 \pm 0.14$ & $22.30 \pm 0.28$ & $30.46 \pm 0.36$ & $158.10 \pm 1.48$ \\
Group IV & $7.56 \pm 0.11$ & $4.16 \pm 0.10$ & $3.40 \pm 0.11$ & $16.27 \pm 0.31$ & $26.27 \pm 0.14$ & $143.12 \pm 2.19$ \\
Group V & $8.01 \pm 0.31$ & $4.23 \pm 0.14$ & $3.78 \pm 0.25$ & $18.16 \pm 0.23$ & $24.30 \pm 0.14$ & $124.66 \pm 2.74$ \\
\hline
\end{tabular}

Each Value is SEM \pm 6 individual observations $* P<0.05 ; * * P<0.01$ Compared normal control vs -Diabetic rats.

Table. 3: Effect of P. rosmarinifolia extract on serum lipid profile in the normal, diabetic and drug treated rats.

\begin{tabular}{|c|c|c|c|c|c|c|}
\hline Groups & $\begin{array}{l}\text { TC } \\
(\mathrm{mg} / \mathrm{dl})\end{array}$ & $\begin{array}{l}\text { TG } \\
(\mathrm{mg} / \mathrm{dl})\end{array}$ & $\begin{array}{l}\text { HDL - C } \\
(\mathrm{mg} / \mathrm{dl})\end{array}$ & $\begin{array}{l}\text { LDL - C } \\
(\mathrm{mg} / \mathrm{dl})\end{array}$ & $\begin{array}{l}\text { VLDL -C } \\
(\mathrm{mg} / \mathrm{dl})\end{array}$ & $\begin{array}{l}\text { PL } \\
(\mathrm{mg} / \mathrm{dl})\end{array}$ \\
\hline I & $103.11 \pm 2.56$ & $92.66 \pm 1.87$ & $21.11 \pm 1.32$ & $63.47 \pm 2.13$ & $18.53 \pm 1.15$ & $159.76 \pm 2.67$ \\
\hline II & $214.19 \pm 1.84 * *$ & $178.26 \pm 2.19 * *$ & $06.29 \pm 2.36^{* *}$ & $92.25 \pm 2.56^{*}$ & $35.65 \pm 1.45$ & $258.62 \pm 3.46$ \\
\hline III & $164.36 \pm 1.20^{\mathrm{a}}$ & $121.12 \pm 1.64^{\mathrm{a}}$ & $18.64 \pm 1.08^{\mathrm{a}}$ & $80.63 \pm 1.26^{\mathrm{a}}$ & $26.48 \pm 1.34$ & $188.54 \pm 2.42$ \\
\hline IV & $108.26 \pm 1.33^{\mathrm{a}}$ & $84.64 \pm 1.72^{\mathrm{a}}$ & $30.16 \pm 1.30$ & $61.18 \pm 1.32^{\mathrm{a}}$ & $16.92 \pm 1.14$ & $164.35 \pm 2.88$ \\
\hline V & $116.84 \pm 1.63^{\mathrm{a}}$ & $91.55 \pm 1.14^{\mathrm{a}}$ & $25.34 \pm 1.11^{\mathrm{a}}$ & $73.19 \pm 1.59^{\mathrm{a}}$ & $18.31 \pm 1.08$ & $171.98 \pm 2.57$ \\
\hline
\end{tabular}

(VLDL- C) (Friedwald et al., 1972), high density lipoprotein cholesterol (HDL-C) (Warnick et al., 1985) and phospholipids (Takayama et al., 1977) were analyzed.

\section{Statistical Analysis}

The data were analyzed using student's t-test statistical methods. For the statistical tests a $p$ values of less than 0.01 and 0.05 was taken as significant.

\section{RESULT AND DISCUSSION}

The phytochemical screening of ethanol extract of Polygala rosmarinifolia whole plant revealed the presence of alkaloid, catechins, coumarin, tannin, saponin, steroid, flavonoid, phenol, sugar, glycoside and xanthoprotein. Acute toxicity study revealed the non-toxic nature of the ethanol extract of P.rosmarinifolia whole plant. Table 1 shows the levels of blood glucose, serum insulin, urea, creatinine and glycosylated haemoglobin of normal, diabetic and drug treated rats. The alloxan induced diabetic rats elicited significant rise in blood glucose from 83.16 to 231.84 $\mathrm{mg} / \mathrm{dl}(p<0.01)$ and a significant decrease in serum insulin level from 14.27 to $5.21(p<0.01)$. On the contrary, diabetic rats treated with ethanol extract of Polygala rosmarinifolia whole plant exhibited decrease in blood glucose and increase in serum insulin significantly at a dose of $100 \mathrm{mg} / \mathrm{kg}$ and $200 \mathrm{mg} / \mathrm{kg}$ body weight. It was observed that ethanol extract of Polygala rosmarinifolia reversed these effects in diabetic animals. It has been reported that using medicinal plant extract to treat alloxan induced diabetic rats results in activation of $\beta$-cells and insulinogenic effects (Shunmugasundaram et al., 2011). Polygala rosmarinifolia may also have brought about hypoglycemic action through stimulation of surviving of $\beta$-cells of islets of langerhans to release more insulin. This was clearly evidenced by the increased levels of serum insulin in diabetic rats treated with Polygala rosmarinifolia. Since the percentage fall in blood glucose levels was different in models with varying intensity of hyperglycemia, it implies that the antihyperglycemic effect of that plant is dependent on the dosage of diabetogenic agent, which in turn leads to $\beta$-cells destruction (Grover et al., 2000). Earlier many plants have been studied for their hypoglycemic and insulin release stimulatory effects. (Pattabiraman and Muthukumaran, 2011; Maruthupandian and Mohan, 2011; Shunmugasundaram et al., 2011; Kala et al., 2012a, 2012b; Shajeela et al., 2012).

A significant elevation in serum constituents, urea and creatinine were observed in alloxan induced diabetic rats (Group II), when compared to control rats. The ethanol extract of $P$. rosmarinifolia whole plant was administered orally $(100 \mathrm{mg} / \mathrm{kg}$ body weight-Group III $200 \mathrm{mg} / \mathrm{kg}$ body weight-Group IV) to rats for 14 days, reversed to urea and creatinine level to near normal. The administration of glibenclamide (Group V) also decreased the levels of urea and creatinine to some extent. Urea is the main end product of protein metabolism. Amino acid deamination takes place in the liver, which is also the site of urea cycle, where 
ammonia is converted into urea and excreted through urine. Urea varies directly with protein intake and inversely with the rate of excretion. Some of the urea is bound to haemoglobin so its concentration in red blood cells is greatly than in the plasma. Renal diseases which diminish the glomerular filteration lead to urea retention and decrease in urea is seen in severe liver disease with destruction of cells leading to impairment of the urea cycle (Ranjna, 1999). Significant $(P<0.05)$ decrease in serum urea observed with diabetic rats treated with $P$. rosmarinifolia $(200 \mathrm{mg} / \mathrm{kg}$ body weight) may not be as a result of liver damage or abnormal functional kidney. Creatinine is a waste product formed in muscle by creatinine metabolism. Creatinine is synthesized in the liver, passes into the circulation and is taken up almost entirely by skeletal muscle. Its retention in the blood is evidence of kidney impairment. The present results show that, the treatment with ethanol extract of $P$. rosmarinifolia whole plant was effective in preventing alloxan induced increase in serum creatinine level when compared in the control.

Glycosylated haemoglobin has been found to be increased over a long period of time in diabetes. During diabetes, the excess of glucose present in blood reacts with haemoglobin to form glycosylated haemoglobin (Alyassin et al., 1981). The rate of glycation is proportional to the concentration of blood glucose. In present study, alloxan induced diabetic rats showed significant increase $(P<0.01)$ glycosylated haemoglobin $\left(\mathrm{HBA}_{1} \mathrm{C}\right)$ level compared with normal rats. The ethanol extract of $P$. rosmarinifolia whole plant treated rats showed a significant decrease $(P<0.05)$ in the content of glycosylated haemoglobin that could be due to an improvement in glycemic status.

The levels of serum protein, albumin and globulin of control, alloxan induced diabetic rats and drug treated rats were presented in Table 2. A significant reduction in serum protein, albumin and globulin were observed in alloxan induced diabetic rats (Group II) when compared to control (Group I) and glibenclamide treated rats (Group V). This is in agreement with hypoalbuminemia observed in diabetes (Porte and Hatler ,1981). On the other hand, in the $P$. rosmarinifolia extract treated diabetic rats protein metabolism never deviated from normal range. Hypoalbuminemia is a common problem in diabetic animals and is generally attributed in the presence of nephropathy. An overall reduction in serum total protein in diabetic animals and consequents albumin were observed in the present study. The reversal of these changes by ethanol extract of $P$. rosmarinifolia therapy proved that insulin deficiency has been grossly corrected.

Table 2 summarized the effect of alloxan on the activity of the hepatic marker enzymes in serum. There is an increase in transaminase activities in the serum of diabetic animals. The increased levels of transaminases, which are active in the absence of insulin because of increased availability of amine acids in diabetes, are responsible for the increased glucogenesis and ketogenesis observed in diabetes (Sivajothi et al., 2008). There is an improvement noticed in the levels of SGOT, SGPT and ALP are as a consequence of improvement in the carbohydrate, fat and protein metabolism due to the administration of ethanol extract of
P. rosmarinifolia. The restoration of SGOT, SGPT and ALP to their normal levels may be due to the presence of flavonoids in the ethanol extract of $P$. rosmarinifolia, which are reported to be hepatoprotective agents (Ahmed et al., 2000).

The levels of serum lipid profile, total cholesterol (TC), triglycerides (TG), LDL-C, VLDL-C and HDL-C in control, diabetic induced and drug treated rats were presented in Table 3. Alloxan induced rats showed significant increase in serum lipid profiles except HDL-C when compared with normal rats. The glibenclamide (Group V) and ethanol extract of P.rosmarinifolia (Group III and IV) treated rats showed a significant decrease in the content of lipid profiles when compared with diabetic induced rats. Similarly HDL-C level decreased in alloxan induced diabetic rats when compared to normal rats. On administration of ethanol extract of $P$. rosmarinifolia and glibenclamide to the diabetic rats, HDL-C level was found to be restored to normal. A variety of derangements in metabolic and regulatory mechanisms, due to insulin deficiency are responsible for the observed accumulation of lipids (Rajalingam et al., 1993). The impairment of insulin secretion results in enhanced metabolism of lipids from the adipose tissue to the plasma. Further it has been reported that diabetic rats treated with insulin shows normalized lipid levels (Pathak et al., 1981). Thus the results indicate that $P$. rosmarinifolia shows insulin- like action by virtue of its lipid lower levels. Phospholipids were increased in alloxan induced diabetic rats. Phospholipids are present in cell membrane and makeup vast majority of the surface lipoprotein forming a lipid bilayer that acts as an interface with polar plasma environment and non-polar lipoprotein core (Cohn and Roth, 1996).Increased phospholipids levels in tissues were reported by Venkateswaran $e t$ al., (2002) and Pari and Satheesh (2004) in alloxan diabetic rats. Administration of ethanol extract of $P$. rosmarinifolia whole plant and glibenclamide decreased the levels of phospholipids.

It is concluded that, medicinal plants have been reported to possess antihyperglycemic activity. $P$. rosmarinifolia whole plant is gaining much importance in diabetic control, since the phytochemical analysis has shown the presence of potent phytochemicals like flavonoids, glycosides, steroids, tannins, saponin and phenols. Several authors reported that flavonoids, steroids, terpenoids, phenolic acids are known to be bioactive antidiabetic principles (Oliver 1980). Flavonoids are known to regenerate the damaged beta cells in the alloxan induced diabetic rats and acts as insulin secretagogues (Chakravarthy et al., 1980). Saponin reduces the uptake of certain nutrients including glucose and cholesterol at the gut through intraluminal physicochemical reaction. Hence, it has been reported to have hypocholesterotemic effect and thus may aid lessening metabolic burden that would have been placed in the liver (Rajan et al., 2012). In the present study, the phytochemical analysis of ethanol extract of $P$. rosmarinifolia clearly pointed out the presence of above said active phytochemicals. It denotes that the antidiabetic effect of ethanol extract of $P$. rosmarinifolia may be due to the presence of more than one antihyperglycemic principle and their synergistic effects. 


\section{ACKNOWLEDGEMENT}

The Authors wishes to thank Dr. R. Sampatharaj, Honorary Advisor, Samsun Clinical Research Laboratory, Tirupur, for their assistance in animal studies.

\section{REFERENCES}

Zimmet PZ. Diabetes epidemiology as a tool to trigger diabetic research and care. Diabetologia.1999; 42: 499-518.

Pradeepa R. and Mohan V. The changing of the diabetes epidemic implications for India. Indian J Med Res. 2002; 116: 121-132.

Aravind K., Pradeepa R. and Deepa R. Diabetes and coronary artery disease. Indian J Med Res. 2002; 116:163-176.

Ugochukwu NH., Babady NE., Cobourne M. and Garret SR. The effect of Gangronema latifolium extracts on serum lipid profile and oxidative stress in hepatocytes of diabetic rats. J Biosci. 2003; 28: 1-5.

Scoppria A., Monteechi FR., Mezinger G. and Lala A. Urinary mevalonate excretion rate in type 2 diabetes: role of metabolic control. Alherosclersis. 2001; 156: 357-361.

Owu DU., Antai AB., Udofia KH., Obembe AO., Obasi KO. and Etery MV. Vitamin $\mathrm{C}$ improves basal metabolic rate and lipid profile in alloxan induced diabetes mellitus in rats. J Biosci. 2006; 31:575-579.

Kesavulu MM., Giri R., Kameswara RB. and Apparao C. Lipid peroxidation and antioxidant enzyme levels in type 2 diabetes with microvascular complications. Diabetic Metabol. 2000; 26:387-392.

Trivedi NA., Majumder B., Bhatt JD. and Hemavathi KG. Effect of Shilajit on blood glucose and lipid profile in alloxan induced diabetic rats. Indian J Pharmacol. 2004; 36: 373-376.

Sharma VK., Kumar S., Patel HJ. and Hugar S. Hypoglycemic activity of Ficus glomerata in alloxan inducd diabetic rats. Int $J$ Pharmaceu Sci Rev Res. 2010; 1: 18-23.

Yoon SL., Horne CH. and Adams C. Herbal product use by African older women. Clin Nurs Res. 2004; 13:271-288.

Shukla R., Sharma SB., Puri D., Prabha KM. and Murthy PS. Medicinal plants for treatment of diabetes mellitus. Indian J Clin Biochem 2000; 15:169.

Brinda P., Sasikala P. and Purushothaman KK. Pharmacognostic studies on Merugan kizhangu. Bull Med Ethnobot Res. 1981; 3: 84-96.

Lala PK. Lab manuals of Pharmacognosy CSI Publishers and Distributers, Kolkata (1993).

OECD. Organisation for Economic co-operation and Development. OECD guidelines for the testing of chemicals/Section 4: Health Effects Test No. 423; Acute oral Toxicity- Acute Toxic Class method. OECD. Paris (2002).

Nagappa AN., Thakurdesai PA., Venkat Rao N. and Sing J. Antidiabetic activity of Terminalia catappa Linn. fruits. $J$ Ethnopharmacol. 2003; 88: 45-50.

Sasaki T., Masty S. and Sonae A. Effect of acetic acid concentration on the colour reaction in the Otoluidine boric acid method for blood glucose estimation. Rinshbo Kagaku, 1972; 1: 346-353.

Anderson L., Dinesen B., Jorgonsen PN., Poulsen F. and Roder ME. Enzyme immune assay for intact human insulin in serum or plasma. Clin Chem. 1993; 39: 578-582.

Varley H. (1976) Practical clinical biochemistry, Arnold Heinemann Publication Pvt. Ltd. p, 452.

Owen JA., Iggo JB., Scangrett FJ. and Steward IP. Determination of creatinine in plasma serum, a critical examination. $J$ Biochem. 1954; 58: 426-437.

Karunanayake EH. and Chandrasekharan NV. An evaluation of a colorimetric procedure for the estimation of glycosylated haemoglobin and establishment of reference values for Sri Lanka. J Nat Sci Coun Sri Lanka. 1985; 13: 235-258.

Lowry OH., Rosenbrough NJ., Farr AL. and Randall RJ. Protein measurement with the Folin's phenol reagent. J Bio Chem. 1951; 193: 265-275.
Reitman S. and Frankel SA. Colorimetric method for the determination of serum glutamic oxaloacetic and glutamic pyruvic transaminases. Amer J Clin Path. 1957; 28: 56-63.

King EJ. and Armstrong AR. Determination of serum and bile phosphatase activity. Cannad Med Assoc J. 1934; 31: 56-63.

Parekh AC. and Jung. Cholesterol determination with ferric acetate, uranium acetate and sulphuric acid, ferrous sulphate reagent. Anal Chem. 1970; 112: 1423-1427. Rice EW. (1970) Triglycerides in Serum In: Standard Methods. Clinical Chemistry. 9ed Roderick MP, Academic press, (pp 215-222) New York.

Friedwald WT., Levy RI. and Fredrickson DS. Estimation of the concentration of low density lipoprotein cholesterol in plasma, without use of the preparative ultra centrifuge. Clin Chem. 1972; 18: 499-502.

Warnick GR., Nguyan T. and Albers AA. Comparison of improved precipitation methods for quantification of high density lipoprotein cholesterol. Clin Chem. 1985; 31: 217-22.

Takayama M., Itoh S., Nagasaki T. and Tanimizu I. A new enzymatic method for determination of serum phospholipids. Clin Chem Acta. 1977; 79: 93 - 98

Shanmugasundaram R., Kalpana Devi V., TresinaSoris P., Maruthupandian A. and Mohan VR. Antidiabetic, antihyperlipidaemic and antioxidant activity of Senna auriculata (L.) Roxbleaves in alloxan induced diabetic rats. Int J Pharm Tech Res. 2011; 3: 747-756.

Grover JK., Vats V. and Rathi SS. Antihyperglycemic effect of Eugenia jambolana and Tinospora cardifolia in experimental diabetes and their effects on key metabolic enzymes involved in carbohydrate metabolism. J Ethnopharmacol. 2000; 73: 461-470.

Pattabiraman K. and Muthukumaran P. Antidiabetic and antioxidant activity of Morinda tinctoria Roxb fruits extract in Streptozotocin- induced diabetic rats.

Maruthupandian A. and Mohan VR. Antidiabetic, antihyperlipidaemic and antioxidant activity of Pterocarpus marsupian Roxb. in alloxan induced diabetic rats. Asian J Pharm Tech. 2011; 1:3439

Kala SMJ., Tresina PS. and Mohan VR. Antioxidant, antihyperlipidaemic and antidiabetic activity of Eugenia floccosa Bedd leaves in alloxan induced diabetic rats. J Basic Clin Pharmacy. 2012a; 3: 235-240.

Kala SMJ, Tresina PS, Mohan VR. Antioxidant, antihyperlipidaemic and antidiabetic activity of Eugenia singamattina Bedd leaves in alloxan induced diabetic rats. Int J Pharma Pharmaceu Sci. 2012b; 4: 412-416.

Shajeela PS., Kalpanadevi V. and Mohan VR. Potential antidiabetic, hypolipidaemic and antioxidant effects of Nymphaea pubercens extract in Alloxan induced diabetic rats. J Appl Pharmacu. Sci. 2012; 2: 83-88.

Ranjna C. Practical clinical biochemishy methods and interpretation $2^{\text {nd }}$ edn, (1999) p.117.

Alyassin D. and Ibrahim KA. Minor haemoglobin fraction and the level of fasting blood glucose. J Fac Med Gnive Baghdad.1981; 23: 373-380.

Porte DJ. and Halter JB. (1981) Text book of Entoerinology.WB saundersCO. Philadelphia p.715.

Ahmad AA., Shoib A., Tahira M. and Anwar H. Hypoglycemic action of the flavonoid fraction of Cuminium nigram seeds. Phytother. Res. 2000; 14:103-106.

Rajalingam R., Srinivasan N. and Govindarajulu P.1993. Effect of alloxan iduced diabetes on lipid profiles in renal cortex and medulla of mature albino rats. Indian J Exp Biol. 1993; 31: 577-579.

Pathak RM., Ansai S. and Mahmood A. Changes in chemical composition of intertional brush border membrane in alloxan induced chronic diabetes. Indian J Exp Biol.1981; 19: 503-505.

Cohn RM. and Roth KS. (1996) Lipid and lipoprotein metabolism In: Biochemistry and Diseases, Williams and Willkins publishers, Baltimore. p 280.

Venkateswaran S., Pari L. and Saravanan G. Effect of Phaseolus vulgaris on circulatory antioxidants and lipids in streptozotocininduced diabetic rats. J Med Food. 2002; 5: 97 - 104. 
Pari L. and Satheesh AM. Antidiabetic effect of Boerhavia diffusa: effect on serum and tissue lipids in experimental diabetes. J Med Food. 2004; 7: $472-476$.

Oliver B. Oral hypoglycaemic plants in West Africa. $J$ Ethnopharmacol. 1980; 2: 119-127.

Chakravarthy BK., Gupta S., Gambir SS. and Gode KD. Pancreatic beta cell regeneration. A novel antidiabetic mechanism of Pterocarpus marsupium Roxb. Ind J Pharmacol. 1980; 12: 123 - 127.
Rajan M., Kumar KV., Kumar PS., Swasthi KR. and Haritha S. Antidiabetic, antihyperlipidaemic and hepatoprotective activity of methanolic extract of Ruellia tuberose linn leaves in normal and alloxan induced diabetic rats. J Chem Pharmaceu Res.2012:4:2860-2868.

\section{How to cite this article:}

M. Alagammal, A. Nishanthini, V.R. Mohan. Antihyperglycemic and Antihyperlipidaemic effect of Polygala rosmarinifolia Wright \& Arn on alloxan induced diabetic rats. J App Pharm Sci. 2012; 2(9): 143-148. 